- FINANSE I PRAWO FINANSO WE.

- Journal of Finance and Financial Law .

Grudzień/December 2018 • vol. 4(20): 57-72

https://doi.org/10.18778/2391-6478.4.20.05

\title{
PRANIE PIENIĘDZY W ŚWIETLE REGULACJI FINANSOWYCH
}

Tomasz Jaszek

Wydział Finansów i Prawa

Uniwersytet Ekonomiczny w Krakowie

\begin{abstract}
Streszczenie
Proceder prania pieniędzy zalicza się do kategorii przestępstw o charakterze gospodarczym. Skala tego zjawiska stanowi temat wielu dyskusji i rozważań na arenie międzynarodowej. Światowe organizacje takie jak OECD czy FATF podejmują liczne inicjatywy wobec realnego zagrożenia dla rynku finansowego. Efektem współpracy międzynarodowej jest opracowanie przez Unię Europejską istotnej regulacji prawnej, rozpoznawanej jako Dyrektywa AML IV, którą państwa członkowskie obowiązane są wprowadzić do krajowego porządku prawnego. Konceptem unijnej regulacji jest wzmocnienie spójności oraz wiarygodności sektora finansowego Wspólnoty. Także w Polsce zostały opracowane rozwiązania prawno-instytucjonalne, których zamysłem jest skuteczne i efektywne zwalczanie procesu prania pieniędzy. Celem niniejszego artykułu jest przegląd polskich rozwiązań regulacyjnych mających na celu przeciwdziałanie procederowi prania pieniędzy.
\end{abstract}

Słowa kluczowe: pranie pieniędzy, AML/CFT, przestępstwo gospodarcze, nadużycie, oszustwo, instytucja obowiązana.

JEL Class: K4, K29. 


\section{WPROWADZENIE}

Przestępczość gospodarcza występuje w każdym państwie na świecie. Nie sposób przeoczyć także licznych afer finansowych, związanych z podatkami i rajami podatkowymi. Proces optymalizacji podatkowej sam w sobie nie jest zły, jednakże coraz częściej wykorzystywany jest do prania pieniędzy przez podmioty prowadzące działalność niezgodną $\mathrm{z}$ literą prawa. Problem ten jest o tyle istotny, ponieważ wpływa na stabilność gospodarki, a także na poziom bezpieczeństwa danego kraju. W proceder prania pieniędzy zaangażowane są również liczne instytucje finansowe, które muszą podejmować coraz bardziej zdecydowane działania mające na celu przeciwdziałanie temu zjawisku. Przeciwdziałanie, jak i inicjatywy o charakterze prewencyjnym, są możliwe do realizacji dzięki współpracy instytucji i organów nie tylko na szczeblu krajowym, lecz także na poziomie międzynarodowym.

Nie pozostawia jednak wątpliwości potrzeba wyodrębnienia tej przestępczości z pozostałych kategorii, z uwagi na jej istotę o charakterze społeczno-ekonomicznym, a zwłaszcza uwarunkowania. Ewoluowanie przestępczości gospodarczej oraz jej stopień skomplikowania pod względem podmiotowym i przedmiotowym uniemożliwia stworzenie jednej, ogólnej i uniwersalnej defini-

cji przestępczości gospodarczej [Wilk 2012: 14]. Oktawia Górniok słusznie podkreśla jej trwały i uniwersalny charakter, z uwagi na zależności między sposobem i uwarunkowaniami danej społeczności a kryminalizacją poszczególnych zachowań ekonomicznych. Warto przy tym zaznaczyć, że niektóre części składowe systemu gospodarczego, względnie branże gospodarki, są szczególnie kryminogenne [Wójcik 2008: 21]. Przestępczość gospodarcza jest w swej istocie niebywale skomplikowana, ale jak twierdzi Karol Schneider, „wydaje się być dość bezpiecznym sposobem zdobywania w nielegalny sposób pieniędzy, ponieważ rozbój i kradzież to od wieków znane przejawy działalności przestępczej”. Ta patologia gospodarcza nie przejawia się zatem w szczególnie brutalnych, kryminalnych zachowaniach, lecz raczej czymś innym, co określa się jako przestępczość dokonywaną przez osoby w tzw. białych kołnierzykach. Wprawdzie przestępczość gospodarcza jest marginalnym zachowaniem, to jednak zawsze znajdzie się osoba, która zechce szybciej osiągnąć ponadprzeciętne rezultaty. Natomiast zupełnie odmienne procesy występują w przypadku funkcjonowania zorganizowanych grup przestępczych.

\section{POJĘCIE PRANIA PIENIĘDZY}

Za miejsce powstania procederu prania pieniędzy uznaje się Chicago, w którym to mieście działała mafia pod przywództwem Al Capone. W latach dwudziestych ubiegłego wieku, jego grupa przestępcza osiągała znaczne dochody z pro- 
dukcji alkoholu. Prowadzona działalność miała legalny charakter handlowo-usługowy. Wkrótce grupa przestępcza przejmowała kontrole nad cukierniami, sklepami spożywczymi, ale przede wszystkim skupiła się na rynku pralni. To właśnie w pralniach dochodziło do „prania pieniędzy”, polegającego na tym, że do codziennych przychodów dodawano większe sumy, w celu legalizacji pieniędzy pochodzących z nielegalnych i nieuczciwych źródeł. W tym okresie zjawisko prania pieniędzy było bardzo rzadkie, stąd zdarzenia takie nie były klasyfikowane jako niezależny rodzaj działalności [Wójcik 1997: 31].

Pomimo krótkiej historii terminologii, zjawisko prania pieniędzy sprowadzające się do przestępczej działalności motywowanej finansowym zyskiem posiada relatywnie długą historię. Ów proceder nie jest nowym zjawiskiem pośród przestępstw godzących w pewność obrotu finansowego. W ciągu zaledwie ostatnich kilkunastu lat, termin ,prania pieniędzy” wszedł do potocznego języka w większości krajów świata. Warto podkreślić, iż po raz pierwszy posłużono się tym terminem już po I wojnie światowej w Stanach Zjednoczonych [Gruszczyński 2014: 8], a jesienią 1984 r. na łamach szwajcarskiej prasy ukazano takie sformułowania, jak: czyszczenie, pracz lub pranie pieniędzy [Gruszczyński 2014].

Ukształtowane w latach dwudziestych XX wieku [Lilley 2006: 19] zjawisko prania pieniędzy nie wyróżnia się jednorodną definicją. Występuje ono w każdym kraju na świecie i w związku z postępującą globalizacją staje się sporym problemem transgranicznym o negatywnych skutkach dla społeczeństwa i gospodarki. Cechą tego zjawiska jest zatem jego wymiar społeczno-finansowy, co implikuje potrzebę analizy nie tylko przez środowisko prawnicze, lecz także przez ekonomistów [Gołębiewska 2014: 23]. Etymologia słowa wywodzi się z wykorzystania do omawianego procederu form aktywności gospodarczej charakteryzujących się szybkim, rzeczywistym przepływem gotówki, na przykład pralni, restauracji, kasyn [Chodnicka 2011: 120]. Termin ,pranie pieniędzy” ma liczne synonimy, do których można zaliczyć [Gołębiewska 2014: 24]:

- wybielanie,

- czyszczenie,

- czarne pieniądze,

- czarny rynek.

W Europie, prawna definicja tego zjawiska została określona w Dyrektywie 2015/849 Parlamentu Europejskiego i Rady Unii Europejskiej z dnia 20 maja 2015 r. w sprawie przeciwdziałania korzystaniu z systemu finansowego w celu prania pieniędzy oraz finansowania terroryzmu. W niniejszym akcie prawnym, mającym znaczenie dla Europejskiego Obszaru Gospodarczego, za pranie pieniędzy uznaje się następujące czyny popełnione umyślnie [Dyrektywa Parlamentu Europejskiego i Rady UE 2005/60/WE..., art. 1 ust. 2]: 
- konwersję lub przekazywanie mienia, ze świadomością, że pochodzi ono z działalności przestępczej lub z udziału w takiej działalności, w celu ukrywania lub zatajania nielegalnego pochodzenia tego mienia albo udzielenia pomocy osobie, która bierze udział w takiej działalności, dla umożliwienia jej uniknięcia konsekwencji prawnych takiego działania,

- ukrycie lub zatajenie prawdziwego charakteru mienia, jego źródła, miejsca położenia, rozporządzania nim, przemieszczania, własności lub praw do mienia, ze świadomością, że mienie to pochodzi z działalności przestępczej lub z udziału w takiej działalności,

- nabycie, posiadanie lub korzystanie z mienia, ze świadomością w momencie jego otrzymania, że mienie to pochodzi z działalności o charakterze przestępczym lub z udziału w takiej działalności,

- udział lub współdziałanie w popełnieniu, usiłowanie popełnienia, jak też pomocnictwo, podżeganie, ułatwianie oraz doradzanie przy popełnieniu czynów określonych w powyższych punktach.

Podobną definicję można znaleźć w polskim ustawodawstwie, która opiera się o powyższe założenia Dyrektywy Parlamentu Europejskiego i Rady.

\section{RYZYKO I SKUTKI PRANIA PIENIĘDZY}

Czyszczenie i legalizacja dochodów mających nielegalne źródło pochodzenia, stały się w XX wieku na tyle widocznym problemem, iż międzynarodowe organizacje i rządy wielu państw były zainteresowane znacznym ograniczeniem lub całkowitą eliminacją tego procederu. Proces prania pieniędzy, jego powszechność i wykorzystanie przez organizacje przestępcze przyczyniły się do powstania wielu zagrożeń dla życia gospodarczego i bezpieczeństwa finansowego wielu krajów. Wybielanie pieniędzy może mieć destabilizujący wpływ na funkcjonowanie gospodarek poszczególnych krajów, gdy dochody z działalności przestępczej stanowią równowartość rocznego PKB danego kraju. W kontekście możliwych zakłóceń gospodarczych krajów na świecie, pranie pieniędzy może powodować zakłócenia w systemie fiskalnym, pojawianie się korumpowania pracowników instytucji obowiązanych, naruszanie zasad uczciwej konkurencji, a nawet przejmowanie niektórych sektorów gospodarki przez zorganizowane grupy przestępcze [Gołębiewska 2014: 55]. Proceder prania pieniędzy, przez wzgląd na rozmiar w globalnej gospodarce, może zagrażać w istotny sposób instytucjom finansowym, powodując utratę zaufania społecznego do instytucji finansowych. Spoglądając na efekty prania pieniędzy można dostrzec, iż przyczyniają się one do umocnienia gospodarczego grup przestępczych oraz mogą stanowić niezbędne wsparcie dla działalności terrorystycznej, w konsekwencji czego powstaje realne zagrożenie utrzymania bezpieczeństwa społeczeństwa 
danego kraju na właściwym poziomie. Zasadniczo można posłużyć się stwierdzeniem Magdaleny Hryniewickiej [2014: 319], iż pranie pieniędzy to takie czynności, które mają na celu ukrycie prawdziwego źródła pochodzenia nielegalnych dochodów, a w konsekwencji nadanie im cech legalnego pochodzenia.

Działające w Polsce organizacje, będące jednocześnie instytucjami obowiązanymi, w myśl ustawy z dnia 16 listopada 2000 r. o przeciwdziałaniu praniu pieniędzy oraz finansowania terroryzmu [Dz.U. 2000, nr 116, poz. 1216], które chcą sprostać wymaganiom wynikającym z oczekiwań społecznych i środowisk interesariuszy oraz takich zmian jak utrzymanie prestiżu, reputacji firmy czy dostosowaniu się do konsekwencji procesów globalizacji, powinny nieustannie doskonalić systemy zarządzania ryzykiem, w tym ryzykiem prania pieniędzy.

Instytucje obowiązane, a wśród nich instytucje finansowe, w procesach zarządzania ryzykiem powinny prowadzić analizę wielu aspektów wynikających z prowadzonej działalności biznesowej w licznych obszarach działań rynkowych, społecznych, środowiskowych i etycznych [Gołębiewska 2014: 35]. Nawiązując do stwierdzenia autorki publikacji Zarządzanie zmianami, warto zapamiętać, że „efektem doskonalenia organizacji w zakresie zarządzania ryzykiem jest uodpornienie organizacji na zakłócenia" [Masłyk-Musiał 2002: 8]. Ocena efektywności zarządzania ryzykiem prania pieniędzy oraz wskazanie istotnych elementów wpływających na poprawę funkcjonowania organizacji i międzynarodowego systemu przeciwdziałania praniu pieniędzy w odniesieniu do wartości etycznych jest zagadnieniem niezwykle interesującym. Proces ten stanowi aktualnie nowy nurt badań w obszarze zarządzania systemami bezpieczeństwa ekonomicznego i społecznego oraz nauk o zarządzaniu.

Oszacowanie skali zjawiska prania pieniędzy jest niezwykle trudne. Warto zauważyć, że problem ten nie dotyczy jedynie Polski, lecz ma on charakter międzynarodowy. Z szacunków Międzynarodowego Funduszu Walutowego wynika, iż koszty prania pieniędzy i związanych $\mathrm{z}$ tym zjawiskiem przestępstw wynosi od 2 do 5\% światowego PKB [Soto 2014: 11]. Eksperci z Kanady szacują z kolei skalę zjawiska na 5-15 mld dolarów rocznie, a w Wielkiej Brytanii za pomocą brytyjskich instytucji finansowych roczna kwota pranych pieniędzy oscyluje w granicach 15 mld funtów brytyjskich [Hryniewicka 2014: 323-324].

Jak wynika z Raportu o stanie bezpieczeństwa w Polsce w 2016 roku, największe straty dla budżetu państwa występują w wyniku przestępstw gospodarczych [Raport o stanie bezpieczeństwa w Polsce w 2016 r.: 143], które liczone są w miliardach złotych. Nielegalna działalność gospodarcza wpływa także negatywnie na sektor prywatny poprzez bezpośrednie zmniejszenie dochodów oraz spadek konkurencyjności w związku z rozwojem szarej strefy czy zaniżaniem kosztów działalności przez podmioty gospodarcze funkcjonujące i prowadzące swoją działalność z naruszeniem prawa. Przestępstwa te naruszają również interesy uczestników obrotu gospodarczego przez zakłócanie uczciwej konkurencji. 
Zasięg procederu prania pieniędzy nie jest ograniczony do granic danego państwa, lecz osiąga charakter zjawiska międzynarodowego. Skutki legalizacji środków pieniężnych pochodzących z niedozwolonych źródeł obejmują swoim zasięgiem praktycznie cały świat, a zorganizowane grupy przestępcze wykształciły w ramach swoich struktur zdolność do funkcjonowania w otaczającym je środowisku z coraz większym natężeniem, szczególnie podczas występowania zjawisk kryzysowych. Mechanizm prania pieniędzy w ujęciu transgranicznym polega na transferze znacznych sum pieniędzy z państwa, w którym uzyskano dochody z nielegalnego źródła, do krajów, których systemy prawne umożliwiają konwersję brudnych pieniędzy na dochody legalne. Kraje sprzyjające legalizacji nielegalnych dochodów określane są mianem rajów podatkowych [Hryniewicka 2014: 318]. Przestępstwa tego rodzaju są efektem rozwoju nowych technologii informatycznych, do których dostęp ma zarówno sektor usług finansowych i organy skarbowe, ale także osoby dokonujące przestępstw finansowych.

Pranie pieniędzy przyczynia się do utraty stabilności makroekonomicznej kraju. Środki związane z działalnością przestępczą charakteryzują się wysoką płynnością, wywołując w przypadku krajów rozwijających się zauważalne wahania kursów walutowych, agregatów pieniężnych czy poziomu cen [Chodnicka 2015: 70]. Napływ do gospodarki środków pochodzących z nielegalnej działalności skutkuje także jej drenażem wynikającym z ich spekulacyjnego charakteru oraz krótkookresowych inwestycji. Część środków finansowych pochodzących z prania pieniędzy i pozostających do dalszego finansowania nielegalnej działalności o charakterze przestępczym, nie pojawia się w oficjalnych statystykach dotyczących zarządzania zmiennymi makroekonomicznymi, takimi jak stopy procentowe, podaż pieniądza, inflacja czy kursy walut [Chodnicka 2015: 71]. Konsekwencją jest zniekształcenie danych potrzebnych do właściwego prowadzenia polityki ekonomicznej. Ponadto, pranie pieniędzy wywołuje negatywne efekty w przepływie kapitału. Szczególnie kraje o rozwiniętych rynkach finansowych są podatne na zagrożenie wynikające z napływu środków z nielegalnych źródeł celem ich legalizacji. Pranie pieniędzy niesie za sobą wiele negatywnych i niekorzystnych skutków dla gospodarki i społeczeństwa. Patrycja Chodnicka [2015] odwołując się do badań Peter'a Quirk’a podkreśla, że legalizacja dochodów pochodzących $\mathrm{z}$ nielegalnej działalności powoduje powstanie zagrożenia dla systemu finansowego wielu krajów.

Kraje, które wdrożyły mało restrykcyjne rozwiązania prawne mające na celu podjęcie działań przeciwko procederowi prania pieniędzy, mogą być narażone na sankcje ze strony kluczowych partnerów gospodarczych. Państwa ułatwiające pranie pieniędzy nie dostosowują się do ogólnoświatowych rozwiązań w zakresie przeciwdziałania temu zjawisku. Skutkiem celowego niedopasowania przepisów do powszechnie obowiązujących może być ograniczony dostęp do środków finansowych. 


\section{POLSKIE ROZWIAZZANIA LEGISLACYJNE DOTYCZĄCE ZWALCZANIA PROCEDERU PRANIA PIENIĘDZY}

Upadek systemu centralnego planowania oraz położenie geograficzne na szlaku tranzytowym pomiędzy Europą Zachodnią a krajami byłego Związku Radzieckiego to tylko jedne $\mathrm{z}$ wielu pobudek rozwoju zjawiska prania pieniędzy w Polsce. Z przeprowadzonych badań statystycznych wynika, iż po 1989 roku nastąpił dwudziestoprocentowy wzrost przestępczości, a polskie banki zostały uznane za depozytariuszy środków finansowych klientów z Rosji i Afryki Zachodniej [Chodnicka 2015: 126]. Polska stała się atrakcyjnym miejscem czyszczenia pieniędzy dla mafii włoskich, rosyjskich i kolumbijskich, które legalizowały tanio i bezpiecznie nielegalne środki pieniężne. Rocznie przez Polskę przepływało w ten sposób od 3 do 9 miliardów dolarów [Bieniek 2010: 190]. Do dnia 12 października 1994 roku w polskim systemie prawnym nie pojawił się żaden przepis karny, który przewidywałby odpowiedzialność za tzw. pranie pieniędzy. Nie oznaczało to bezkarności za podejmowanie działań niezgodnych z literą prawa. Do momentu uchwalenia artykułu 5 Ustawy o ochronie obrotu gospodarczego, skazanie sprawców prania pieniędzy następowało w oparciu o art. 215 uchylonego Kodeksu karnego [Dz.U. 1969, nr 13, poz. 94] bądź art. 252 tegoż kodeksu. Powyższe przepisy nie były jednak skuteczne wobec wszystkich przestępców, bowiem nie obejmowały możliwości ścigania w szczególności pracowników instytucji obowiązanych za wprowadzenie do obrotu środków, które pochodzily z przestępstwa, nawet gdyby dokonano tego nieumyślnie. Mimo obowiązku zachowania należytej staranności przez pracownika instytucji obowiązanej, który powinien według swojej najlepszej wiedzy, powziąć podejrzenie o nielegalnym pochodzeniu środków [Kaczmarski 2016: 69], również nie było możliwości podjęcia odpowiednich kroków prawnych wobec takiego pracownika.

16 grudnia 1991 roku Rzeczpospolita Polska podpisała ze Wspólnotami Europejskimi oraz Państwami Członkowskimi w Brukseli Układ Europejski, dotyczący współpracy ekonomicznej oraz międzynarodowego dialogu politycznego. Zgodnie z art. 68, Polska została zobowiązana do dążenia osiągnięcia w obecnym i przyszłym ustawodawstwie jednolitości w odniesieniu do regulacji istniejącego ustawodawstwa we Wspólnocie. Dodatkowo, w art. 85 ust. 1 niniejszego dokumentu, ustanowiono potrzebę podjęcia wszelkich działań o charakterze prewencyjnym, mających na celu skuteczne utrudnienie bądź całkowite uniemożliwienie wykorzystania systemu finansowego do legalizacji dochodów z nielegalnej działalności, zwłaszcza pochodzących z przestępstw narkotykowych. Aby zrealizować powyższe zadania, w art. 85 ust. 2 wskazano na potrzebę współpracy o charakterze administracyjno-technicznym w celu wypracowania 
stosownych norm przeciwko zjawisku prania pieniędzy oraz wszelkiej współpracy międzynarodowej w celu implementacji przyjętych norm przez Wspólnotę Europejską i Państwa Członkowskie, a także przez organizacje międzynarodowe, takie jak Grupa Specjalna ds. Przeciwdziałania Praniu Pieniędzy (ang. Financial Action Task Force) [Dz.U. 94.11.38].

Podpisanie Układu Europejskiego oznaczało w praktyce przyjęcie i wdrożenie późniejszych postanowień zawartych w Dyrektywach 91/3083EWF, 2001/97/WE oraz 2005/60/WE [Dz.U. 94.11.38].

Trzymając się chronologicznego porządku, pierwsza inicjatywa skierowana przeciwko praniu pieniędzy w Polsce postulowała nałożenie $75 \%$ podatku dochodowego na osoby, które poniosły znaczne wydatki, a ich legalne pochodzenie nie zostało udowodnione. 23 grudnia 1988 roku weszła w życie ustawa o działalności gospodarczej [Dz.U. 1994, nr 126, poz. 615; stan prawny na dzień: 27.05.2018 r.], która nałożyła na podmioty gospodarcze obowiązek do dokonywania rozliczeń transakcji z wykorzystaniem banków, w przypadku przekroczenia określonych limitów. Rozwiązanie to utrzymano w ustawie z dnia 19 listopada 1999 roku prawo o działalności gospodarczej [Dz.U. 1999, nr 101, poz. 1178 ; stan prawny na dzień: 27.05 .2018 r.].

Za początki ustawodawstwa polskiego $\mathrm{w}$ zakresie obejmującym przeciwdziałanie praniu pieniędzy, uważa się rok 1989, kiedy to uchwalono ustawę Prawo Bankowe [Dz.U. 1997, nr 140, poz. 939; stan prawny na dzień: 27.05.2018 r.]. Na jej podstawie wydano zarządzenie nr 16/92 Prezesa Narodowego Banku Polskiego [Dz.Urz. NBP, nr 9, poz. 20] dotyczące zasad postępowania banków w przypadku ujawniania okoliczności, które wskazywałyby na lokowanie dochodów bądź mienia pochodzącego pośrednio lub bezpośrednio z przestępczej działalności. Na mocy tego zarządzenia, banki zostały zobligowane do dokonywania identyfikacji klientów, którzy wykonywali operacje wpłaty gotówkowej o limicie transakcyjnym wynoszącym 20000 PLN oraz transakcji uznanych za podejrzane. Ponadto, banki zobowiązane zostały do opracowania, wdrożenia i realizowania wewnętrznych przepisów dotyczących przeciwdziałania praniu pieniędzy. W praktyce oznaczało to obowiązek powiadomienia właściwej prokuratury o podejrzeniach zaobserwowania zjawiska prania pieniędzy. W zarządzeniu prezesa NBP po raz pierwszy posłużono się sformułowaniem „pranie pieniędzy”, a także wyróżniono transakcje bankowe mogące stanowić podstawę tego zjawiska. Głównym celem zarządzenia było stworzenie warunków, które umożliwiłyby organom wymiaru sprawiedliwości wykorzystanie informacji oraz pomocy banków. Dokument ten określał pojęcie prania pieniędzy oraz wprowadzał rejestr wszystkich stron transakcji. Konsekwencją całości wydania zarządzenia jest realizacja funkcji pomocniczej w stosunku do przepisów karnych [Chodnicka 2015: 127]. Regulację tą uważa się za początkowy etap 
przystosowywania przepisów prawnych obowiązujących w Polsce do wymogów stawianych przez Unię Europejską.

Kolejnym dokumentem $\mathrm{w}$ zakresie regulacji dotyczących przeciwdziałania legalizacji dochodów pochodzących z nielegalnej działalności było Zarządzenie nr C/2/I/94 Prezesa Narodowego Banku Polskiego z dnia 17 stycznia 1994 roku w sprawie przeciwdziałania wykorzystaniu działalności jednostek organizacyjnych Narodowego Banku Polskiego do wykonywania czynności mających na celu ukrycie pochodzenia środków pieniężnych z przestępstwa lub mających związek z przestępstwem. Powyższe zarządzenie zostało wydane w oparciu o art. 53 ust. 2 ustawy z dnia 31 stycznia 1989 roku o Narodowym Banku Polskim [Dz.U. 1989, nr 4, poz. 22; stan prawny na dzień: 27.05.2018 r.], który dotyczył m.in. [Chodnicka 2015: 127]:

- możliwości oraz potrzeb analizowania rejestrów z uwzględnieniem identyfikacji transakcji podejrzanych,

- zasad rejestracji wpłat,

- zasady przeprowadzania kontroli obejmującej sprawdzenie poprawnego funkcjonowania jednostek organizacyjnych,

- identyfikacji klientów.

W tym samym okresie miały miejsce przygotowania dotyczące kształtowania się przepisów prawnych, których celem było określenie odpowiedzialności karnej za dokonywanie legalizacji dochodów pochodzących z pierwotnej działalności niezgodnej z literą prawa. Zapis dotyczący tego problemu został opisany po raz pierwszy w ustawie z dnia 12 października 1994 roku o ochronie obrotu gospodarczego [Dz.U. 1994, nr 126, poz. 615] oraz zmianie niektórych przepisów prawa karnego, w których ustawodawcy zdecydowali się na wprowadzenie katalogu przestępstw.

Następną regulacją prawną odnoszącą się do zjawiska prania pieniędzy był Kodeks karny z dnia 6 czerwca 1997 roku. W wersji obowiązującej do dnia 23 czerwca 2001 roku, kodeks ten rozróżniał osobę sprawcy z podziałem na przestępstwo źródłowe i główne. Wykładnia prawa prowadziła jednak do wniosku, iż niemożliwe jest, aby sprawca przestępstwa głównego był jednocześnie sprawcą przestępstwa źródłowego, z którego pochodzą nielegalne dochody.

Ustawa o ochronie obrotu gospodarczego została uchylona dnia 1 września 1998 roku dzięki Przepisom wprowadzającym Kodeksu karnego. Badania przeprowadzone w okresie 1995-1997 przez prokuratury apelacyjne pokazują niepokojące statystyki dotyczące przeprowadzonych spraw, co budzi uzasadnione wątpliwości co do skuteczności tej ustawy. Otóż, w tym okresie miały miejsce 54 sprawy, z czego w [Chodnicka 2015: 128]:

- 20 sprawach odmówiono wszczęcia postepowania,

- 17 spraw umorzono,

- 14 spraw było w toku, 
- 3 sprawy zakończyły się aktami oskarżenia wniesionymi do sądu, z czego 2 z 3 zakończyło w drodze wyroku.

Niska skuteczność tej ustawy oraz wysokie koszty jej stosowania i wdrożenia dowodziły jej rażącej nieskuteczności.

Ówczesna Komisja Papierów Wartościowych zobowiązała uchwałą z listopada 1995 roku podmioty prowadzące działalność jako biura maklerskie, do implementacji przepisów mających na celu podjęcie stosownych działań mających na celu zwalczanie legalizacji dochodów mających źródło w działalności niezgodnej z prawem.

Kolejnym dokumentem w polskim systemie prawnym jest ustawa Prawo bankowe z 1997 roku, a zwłaszcza art. 106 ust. 1 tej ustawy. Przepis ten nałożył na banki obowiązek podjęcia zadań, mających na celu przeciwdziałanie wykorzystywaniu funkcji banku do ukrywania wszelakich działań o charakterze przestępczym. Wynika $\mathrm{z}$ tego, iż w razie zaistnienia okoliczności, o których mowa w art. 106 ust. 1 ustawy Prawo bankowe, banki otrzymały od ustawodawcy konkretne wytyczne postępowania, które zostały określone w art. 106 ust. 5 niniejszego aktu prawnego. Na mocy tego przepisu, Komisja Nadzoru Bankowego ustalała w drodze uchwały ściśle określony tryb postępowania banków w sytuacjach, o których mowa w art. 166 oraz art. 299 Kodeksu karnego, a także wysokość, kwoty i warunki rejestru podejrzanych transakcji.

Pojawienie się w polskim systemie prawnym ustawy z dnia 16 listopada 2000 roku o przeciwdziałaniu praniu pieniędzy oraz finansowaniu terroryzmu znacząco wpłynęło na kształt polskiego ustawodawstwa w omawianej dziedzinie. Regulacja ta zmodyfikowała kształt art. 106 ustawy Prawo bankowe w zakresie trybu postępowania banków w sytuacji prania pieniędzy, ustalenia wysokości kwoty oraz warunków prowadzenia rejestru gotówkowych wpłat powyżej określonej kwoty, a także danych o osobach dokonujących wpłaty i na rzecz których wpłata została dokonana. Ponadto, implementacja niniejszego aktu prawnego rozszerzyła przedmiotowy zakres regulacji odnoszących się do przeciwdziałania praniu pieniędzy i stała się kluczowym uzupełnieniem art. 299 Kodeksu karnego.

Przedmiotowy zakres ustawy o przeciwdziałaniu praniu pieniędzy i finansowaniu terroryzmu odnosi się zarówno do wymiaru karnego, jak i przeciwdziałania praniu pieniędzy. Obszerny, jednakże zamknięty katalog podmiotów obowiązanych, jest zgodny z Zaleceniami FATF, dyrektywami i wynikami badań, które zostały przeprowadzone w Stanach Zjednoczonych. Z wyników tych badań wynika, że aż 55 zawodów i profesji jest zaangażowanych w proceder prania pieniędzy. Wśród nich jest wiele uznanych zawodów, m.in. adwokaci, lekarze, właściciele kantorów wymiany walut czy też jubilerzy [Bieniek 2010: 225].

Niejednokrotnie nowelizowana ustawa przeszła największe zmiany pod wpływem ustawy z dnia 25 czerwca 2009 roku o zmianie ustawy o przeciwdzia- 
łaniu wprowadzaniu do obrotu finansowego wartości majątkowych pochodzących z nielegalnych lub nieujawnionych źródeł oraz o przeciwdziałaniu finansowaniu terroryzmu oraz o zmianie niektórych innych ustaw. Nowelizacja miała za zadanie dostosować przepisy ustawy do europejskich standardów, zapewnić stosowanie aktów prawa w obszarze przeciwdziałania finansowaniu terroryzmu, a zwłaszcza względem Zaleceń FATF. Ustawodawca miał także na celu dopasowanie przepisów ustawy o przeciwdziałaniu praniu pieniędzy i finansowaniu terroryzmu do potrzeb dotyczących efektywnego przeciwdziałania implementacji do obrotu finansowego majątkowych wartości mających źródło w nielegalnych bądź nieujawnionych działalnościach. Zamiarem regulatora było także dostosowanie tytułu ustawy oraz stosowanej terminologii w zakresie dotyczącym prania pieniędzy do wykorzystywanej terminologii na arenie międzynarodowej, a w szczególności państw Unii Europejskiej.

\section{INSTYTUCJONALNE ROZWIĄZANIA W POLSCE}

System przeciwdziałania praniu pieniędzy i finansowaniu terroryzmu tworzą zasadniczo trzy instytucje [www1]:

- Generalny Inspektor Informacji Finansowej,

- instytucje obowiązane ${ }^{1}$,

- jednostki współpracujące 2 .

Od 1995 roku w Polsce opracowywano różne koncepcje umiejscowienia agendy zajmującej się przeciwdziałaniem praniu pieniędzy. Do połowy 1998 roku największą popularnością wyróżniał się projekt powołania Państwowej Agencji Informacji Finansowej będącej centralnym organem administracji państwowej. Jesienią tego roku podjęto próbę utworzenia jednostki organizacyjnej, której efektem stało się Krajowe Centrum Informacji Kryminalnej. W jego strukturze znajdował się Wydział Informacji Finansowej, który miał realizować funkcje agendy współpracującej z instytucjami finansowymi oraz pozafinansowymi w zakresie zwalczania procederu prania pieniędzy. W 1999 roku jednostka ta została ostatecznie rozwiązana [Bieniek 2010: 240].

Na mocy art. 3 ustawy o przeciwdziałaniu praniu pieniędzy oraz finansowaniu terroryzmu został utworzony w 2001 roku Urząd Generalnego Inspektora Informacji Finansowej. Przepis ten definiuje GIIF jako organ administracji rządowej adekwatny do podejmowania działań polegających na zapobieganiu wprowadzaniu do obrotu finansowego nielegalnych wartości majątkowych. GIIF

\footnotetext{
${ }^{1}$ Katalog instytucji obowiązanych znajduje się w Dz.U. 2000, nr 116, poz. 1216, art. 2, pkt 1.

${ }^{2}$ Organy administracji rządowej i samorządu terytorialnego oraz inne państwowe jednostki organizacyjne, Komisja Nadzoru Finansowego, Narodowy Bank Polski i Najwyższa Izba Kontroli [Dz.U. 2000, nr 116, poz. 1216, art. 2, pkt 8].
} 
jest centralnym elementem krajowego systemu przeciwdziałania praniu pieniędzy oraz finansowaniu terroryzmu. Generalny Inspektor jest podsekretarzem stanu w Ministerstwie Finansów. Przewodniczący Rady Ministrów powołuje i odwołuje wyznaczoną osobę na to stanowisko na wniosek ministra właściwego do spraw instytucji finansowych. Wykonuje swoje zadania przy pomocy wyodrębnionej jednostki organizacyjnej ze struktury Ministerstwa Finansów.

Zadania GIIF polegają m.in. na gromadzeniu, przetwarzaniu, uzyskiwaniu i analizowaniu informacji, a także podejmowaniu działań, których celem jest przeciwdziałanie wprowadzaniu wartości majątkowych z nielegalnych lub nieujawnionych źródeł do obrotu finansowego [Dz.U. 2000, nr 116, poz.1216, art. 4]. Gromadzone informacje pochodzą od instytucji obowiązanych zgodnie z przepisami ustawy o przeciwdziałaniu praniu pieniędzy oraz finansowaniu terroryzmu i są wprowadzane do bazy danych bądź przechowywane w wersji elektronicznej lub papierowej [Hara i in. 2013a]. Do zadań GIIF należy także rozpoczynanie procedury wstrzymywania transakcji, wobec których zachodzi podejrzenie, iż mają powiązania $\mathrm{z}$ praniem pieniędzy lub środki te pochodzą z szarej strefy. W wyniku otrzymania zawiadomienia od instytucji obowiązanej, w ciągu 24 godzin od jego wpływu GIIF może żądać wstrzymania realizacji podejrzanej transakcji lub blokady rachunku na okres 72 godzin po spełnieniu przesłanek wynikających z art. 18 ust. 1 ustawy [Dz.U. 2000, nr 116, poz. 1216; Hara $\mathrm{i}$ in. 2013b]. W wyniku realizacji tych zadań, tworzone jest zawiadomienie o podejrzeniu popełnienia przestępstwa, które następnie przedstawiane jest uprawnionym organom [Dz.U. 2000, nr 116, poz. 1216, art. 18, 18a, 19].

Generalny Inspektor sprawuje kontrolę nad instytucjami obowiązanymi oraz współpracuje z zagranicznymi podmiotami za pośrednictwem Wydziału Współpracy Międzynarodowej. Jako organ wywiadu finansowego gromadzi dane objęte tajemnicą, poza danymi objętymi tajemnicą państwową [Dz.U. 2000, nr 116, poz. 1216, art. 29], a następnie na pisemny wniosek przekazuje lub może przekazać je uprawnionym podmiotom wymienionych $\mathrm{w}$ ustawie [Dz.U. 2000, nr 116, poz. 1216, art. 32, ust. 1 oraz art. 33]. W stosunku do pozostałych przedmiotów, jakie w świetle przepisów prawnych mogą domagać się udostępnienia tajnych informacji, GIIF podejmuje uznaniową decyzję w przedmiocie ich przekazania, w konsekwencji czego bierze na siebie odpowiedzialność za ochronę tychże danych. Dodatkową kompetencją Generalnego Inspektora jest uprawnienie do inicjowania wymiany informacji z podmiotami zagranicznymi.

Podczas realizacji swoich obowiązków, Generalny Inspektor kooperuje z polską jednostką analityki finansowej, którą jest Departament Informacji Finansowej funkcjonujący w Ministerstwie Finansów. Jednostka ta dokonuje weryfikacji przesłanek zawartych $w$ raportach o kwalifikacji transakcji jako podejrzanej o uczestnictwo $\mathrm{w}$ procederze prania pieniędzy lub finansowania terroryzmu. Następnie gromadzi materiał dowodowy i składa zawiadomienie do proku- 
ratury, która wraz z organami ścigania podejmuje właściwe działania zmierzające do postawienia aktu oskarżenia podejrzanym osobom. $\mathrm{Z}$ danych posiadanych przez polską jednostkę analityki finansowej korzystają jedynie uprawnione podmioty, m.in. prokuratura oraz organy ścigania [Bieniek 2010: 241].

Ze względu na dużą skalę zjawiska prania pieniędzy oraz finansowania terroryzmu, polska jednostka analityki finansowej współpracuje z zagranicznymi jednostkami, a także uczestniczy $w$ pracach organizacji międzynarodowych, działających w omawianej dziedzinie [www1]:

- Grupy Egmont ds. Jednostek Wywiadu Finansowego,

- Komitetu ds. Zapobiegania Praniu Pieniędzy i Finansowaniu Terroryzmu, określanego także jako Komitet Prewencyjny, oraz unijnej Platformy EU-FIU,

- Specjalnego Komitetu Ekspertów Rady Europy ds. Środków Przeciwdziałania Praniu Pieniędzy w Krajach Europy Srodkowej i Wschodniej - MONEYVAL,

- Grupy Specjalnej ds. Przeciwdziałania Praniu Pieniędzy - FATF,

- Grupy Euroazjatyckiej - EAG.

Generalny Inspektor Informacji Finansowej może nałożyć kary finansowe na instytucje obowiązane, w tym banki, do wysokości 750000 PLN w przypadku zaniedbania obowiązku [Chodnicka 2015: 168]:

- zakazu współpracy z bankiem fikcyjnym,

- wykonania w terminie wniosku lub zalecenia pokontrolnego,

- rejestracji transakcji oraz przekazywania GIIF dokumentów z zakresu tej transakcji lub przechowywania przez wymagany okres rejestru tych transakcji oraz dokumentów dotyczących tej transakcji,

- stosowania środków bezpieczeństwa finansowego,

- przeprowadzenia analizy ryzyka w celu użycia odpowiednich środków bezpieczeństwa finansowego,

- zapewnienia udziału pracowników w programie szkoleniowym,

- zamrażania wartości majątkowych osoby, podmiotu lub grupy oraz przekazywania informacji w tym zakresie Generalnemu Inspektorowi,

- przechowywania przez wymagany okres dokumentacji przeprowadzonych analiz.

Kary finansowe stanowią dochód budżetu państwa, a podczas kontroli może zostać nałożona tylko jedna kara [Chodnicka 2015: 169]. Istnieje możliwość złożenia odwołania od nałożonej kary w terminie 14 dni od nałożenia do Ministra Finansów. Informacja o nałożonej karze przekazywana jest organowi nadzorującemu - w przypadku banków jest to Komisja Nadzoru Finansowego. Karom podlegają również osoby reprezentujące interesy instytucji obowiązanej w wymiarze pozbawienia wolności do lat 3 [Dz.U. 2000, nr 116, poz. 1216, art. 35, ust. 1 i 2], chyba że osoba taka działała w sposób nieumyślny, wówczas podlega ona karze grzywny. 
Polska podjęła także współpracę z Europolem. Dokonała tego jeszcze jako kraj kandydujący na członka Unii Europejskiej. 3 października 2001 roku Minister Spraw Wewnętrznych i Administracji podpisał stosowne porozumienie o współpracy z Europejskim Urzędem Policji. Na mocy ustawy z dnia 14 marca 2002 roku o ratyfikacji Umowy między Polską a Europejskim Urzędem Policji o współpracy w zwalczaniu przestępczości, Sejm Rzeczpospolitej wydał Prezydentowi RP stosowne upoważnienie. Porozumienie regulowało możliwe sposoby wymiany oraz przekazywania informacji do Europolu. Umowa zobowiązywała strony do organizacji spotkań kierownictwa polskiego i Europolu, które odbywałyby się przynajmniej raz w roku lub w miarę potrzeb. Współpraca polskiej Policji z Europolem jest możliwa dzięki Biurze Międzynarodowej Współpracy Policji przy Komendzie Głównej Policji. Biuro powstało w dniu 1 stycznia 1994 roku w ramach przekształcenia ówczesnego Krajowego Biura Interpolu. Do zadań Biura należy m.in. realizowanie bezpośredniej koordynacji i współpracy działań między polską Policją oraz innymi organami i uprawnionymi instytucjami do zapobiegania i zwalczania przestępczości a międzynarodowymi formacjami policyjnymi, w celu wspomagania działań o charakterze śledczym i prewencyjnym [Dz.Urz. KGP 2016.13 §18].

Przy GIIF został utworzony na mocy regulacji prawnych Międzyresortowy Komitet Bezpieczeństwa Finansowego, który pełni funkcję opiniodawczą oraz doradczą $\mathrm{w}$ zakresie stosowania szczególnych środków ograniczających przeciwko osobom, podmiotom i grupom [Dz.U. 2000, nr 116, poz. 1216, art. 20d, ust. 5]. W skład Komitetu wchodzą przedstawiciele [Dz.U. 2000, nr 116, poz. 1216, art. 20d, ust. 7] m.in. ministra właściwego do spraw instytucji finansowych, Ministra Sprawiedliwości, Prezesa Narodowego Banku Polskiego czy Generalnego Inspektora.

\section{PODSUMOWANIE}

Konieczność podjęcia działań legislacyjnych stanowi kluczowy element całego systemu prawno-instytucjonalnego wobec procederu prania pieniędzy. Polski ustawodawca na przestrzeni wielu lat dokonał licznych modyfikacji przepisów prawnych dotyczących przeciwdziałania praniu pieniędzy, jak również zarządzaniu ryzykiem związanym z tym zjawiskiem. Instytucje obowiązane wydają się zatem stanowić istotną funkcję w realizacji założeń regulatora, bowiem to na nich ciąży obowiązek zgłaszania odpowiednim instytucjom informacji o transakcjach podejrzanych o uczestnictwo w praniu pieniędzy bądź finansowaniu terroryzmu. Dzięki tym danym możliwe jest podjęcie próby oszacowania skali zjawiska czyszczenia pieniędzy. 
Zjawisko o charakterze przestępczym związanym z praniem pieniędzy nieustannie rozwija się, a przestępcy opracowują coraz to bardziej wyrafinowane metody realizacji działań niezgodnych $\mathrm{z}$ prawem, co powinno rozstrzygać o słuszności ściślejszej kooperacji. Działania legislacyjne nie mogą jednak ograniczać się tylko do nowelizacji istniejących przepisów prawnych. Instytucje aktywnie zaangażowane $\mathrm{w}$ przeciwdziałanie procederowi prania pieniędzy powinny doskonalić współpracę z instytucjami obowiązanymi mocą prawa.

Przykładem rozwiązania instytucjonalnego w Polsce jest organ administracji rządowej - Generalny Inspektor Informacji Finansowej, bowiem współpracuje on $\mathrm{z}$ międzynarodowymi instytucjami oraz posiada dostęp do szerokiego spektrum informacji objętych niejednokrotnie tajemnicą bankową. Możliwość gromadzenia takich danych jest ważna w odniesieniu do sprawowania funkcji kontrolnych. Kompetencje Generalnego Inspektora pozwalają na efektywną realizację powierzonych zadań, co w dłuższym horyzoncie czasowym z pewnością okaże się skutecznym rozwiązaniem instytucjonalnym w kontekście przeciwdziałania procederowi prania pieniędzy.

\section{BIBLIOGRAFIA}

Bieniek B., 2010, Pranie pieniędzy w prawie międzynarodowym, europejskim oraz polskim, Wolters Kluwer, Warszawa.

Chodnicka P., 2015, Pranie pieniędzy. Regulacje i ryzyko sektora bankowego, Wydawnictwo Naukowe Wydziału Zarządzania Uniwersytetu Warszawskiego, Warszawa.

Chodnicka P., 2011, Zastosowanie teorii „crying wolf” $w$ procesie wykrywania prania brudnych pieniędzy, „Prace Naukowe Uniwersytetu Ekonomicznego we Wrocławiu”, nr 166.

Gołębiewska E., 2014, Pranie pieniędzy. Aspekty etyczne $w$ systemie przeciwdziałania praniu pieniędzy, Difin, Warszawa.

Gruszczyński Z., 2014, Zjawisko prania brudnych pieniędzy w świetle polskich uregulowań prawnych, Wyższa Szkoła Gospodarki Krajowej, Kutno.

Hara M., Kierzynka R., Kołodziejski P., 2013a, Komentarz do art. 4 ustawy o przeciwdziałaniu praniu pieniędzy oraz finansowaniu terroryzmu, LexisNexis.

Hara M., R. Kierzynka, P. Kołodziejski, 2013b, Komentarz do art. 18 ustawy o przeciwdziałaniu praniu pieniędzy oraz finansowaniu terroryzmu, LexisNexis.

Hryniewicka M., 2014, Pranie brudnych pieniędzy jako przykład przestępstwa gospodarczego, „Ruch Prawniczy, Ekonomiczny i Socjologiczny”, nr 4.

Kaczmarski M., 2016, Przeciwdziatanie praniu pieniędzy. Krytyczne spojrzenie na taktyczne $i$ prawne aspekty zwalczania prania pieniędzy w Polsce, Difin, Warszawa.

Lilley P., 2006, Brudne interesy, Onepress, Warszawa.

Masłyk-Musiał E., 2002, Zarządzanie zmianami, „Współczesne Zarządzanie”, nr 1(4), Wydawnictwo Uniwersytetu Jagiellońskiego.

Raport o stanie bezpieczeństwa w Polsce w 2016 r., MSWiA.

Soto L., 2014, The economic dimension of money laundering, UIAF.

Wilk L., 2012, Przestępczość gospodarcza - pojęcie, przyczyny, sprawcy, „Edukacja Prawnicza”, nr 10(136). 
Wójcik J. W., 2008, Oszustwa finansowe. Zagadnienia kryminologiczne i kryminalistyczne, Wydawnictwo JWW, Warszawa.

Wójcik J., 1997, Pranie pieniędzy. Studium prawno-kryminologiczne i kryminalistyczne, Wydawnictwo Dom Organizatora, Torun.

[www1] https://www.mf.gov.pl/ministerstwo-finansow/dzialalnosc/giif/system [dostęp: 22.06.2018].

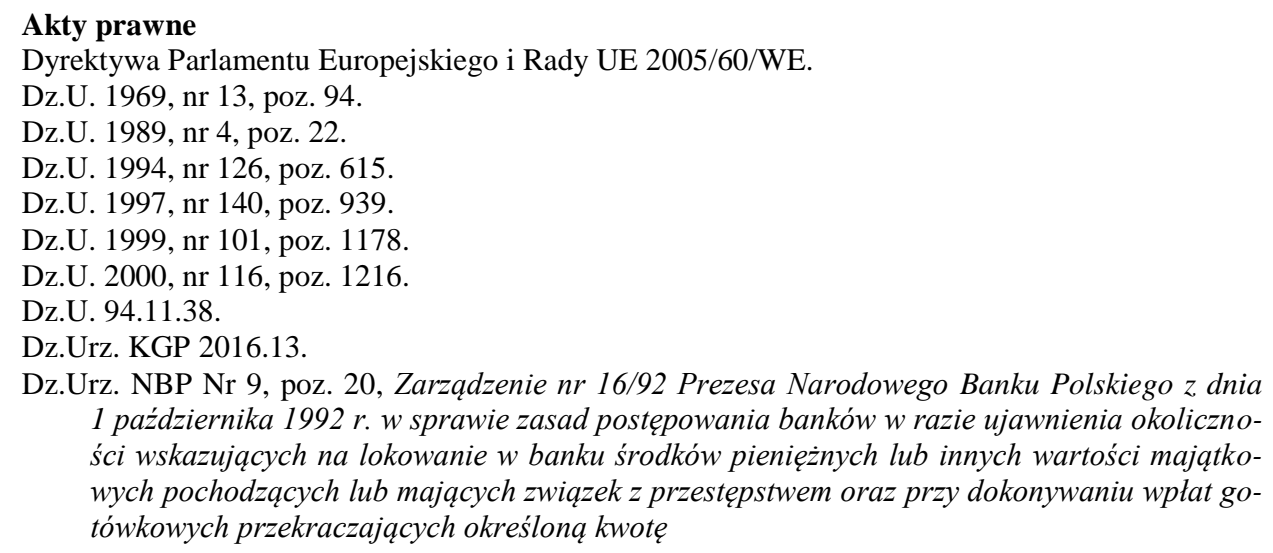

\title{
MONEY LAUNDERING IN THE LIGHT OF FINANCIAL REGULATIONS
}

\begin{abstract}
The money laundering class falls under the category of economic crimes. The scale of this phenomenon is the subject of many discussions and deliberations on the international arena. World organizations such as the OECD or FATF undertake numerous initiatives against a real threat to the financial market. The effect of international cooperation is the development by the European Union of a significant legal regulation, recognized as the AML IV Directive, which Member States are obliged to introduce into the national legal order. The concept of EU regulation is to strengthen the cohesion and credibility of the Community financial sector. Also in Poland, legal and institutional solutions have been developed, the intention of which is to effectively and effectively combat the money laundering process. The purpose of this article is to review Polish regulatory solutions aimed at counteracting money laundering.
\end{abstract}

Keywords: money laundering, AML/CFT, Economic crime, abuse, fraud, obligated institution. 